\title{
Grain yield, quality traits and grain yield stability of local oat cultivars
}

\author{
Zeki Mut ${ }^{1 *}$, Hasan $\mathrm{Akay}^{2}$, Özge Doğanay Erbaş Köse ${ }^{1}$
}

${ }^{1}$ Bozok University, Faculty of Agriculture, Department of Field Crops Yozgat 66100, Turkey. ${ }^{2}$ Ondokuz Mayis University, Faculty of Agriculture, Department of Field Crops Samsun 55130, Turkey*Corresponding author: zeki.mut@bozok.edu.tr

\begin{abstract}
This study was conducted to define grain yield and quality traits of local oat cultivars and to assess the adaptability to and stability of cultivars in different environments of Central and West Black Sea Region of Turkey. Twenty-five oat genotypes were evaluated in a randomized block design with four replications in six different environments. Genotype, environment and genotype $\times$ environment interaction had highly significant effects on grain yield and quality traits. The oat genotypes exhibited significant variations in grain yield $\left(2.15-5.81 \mathrm{t} \mathrm{ha}^{-1}\right)$, test weight (40.8-46.7 kg), thousand-grain weight (21.8-34.2g), groat percentage (70.1-73.6\%), protein (12.013.3\%), ash (2.34-2.77\%), starch (42.7-49.6\%), $\beta$-glucan (2.93-3.56\%), ADF (13.6-16.4\%), NDF (31.5-34.4 $\%$ ) and fat (5.69-6.80). The genotypes G5, G7, G12, G15, and G17 were identified as the most stable cultivars for grain yield. These genotypes also had high values for desired quality traits. Therefore, these genotypes can be recommended for tested environments and similar environments. It was concluded that the genotypes with high values for desired quality traits could be used in further oat breeding programs to improve new cultivars with stable grain yield and high quality.
\end{abstract}

Keywords: Avena sativa, grain yield, quality, stability, oat

\section{Introduction}

Oat (Avena sativa L.) is an important cereal crop and is commonly grown for food and feed. As compared to the other cereals, oat is considered to be more suitable for growing under marginal lands, including cool-wet regions and unfertile-arid lands (Buerstmayr et al., 2007). Oat grains are quite rich in protein and fiber and generally used as a functional food in human nutrition. Test weight, thousand-grain weight, percentage of grouts and chemical composition are the common traits used to characterize and define oat quality. Protein, fat and $\beta$-glucan are important quality indicators for oat grains (Yan et al., 2016). 
Plant breeders have long been working to develop high-yield and consistent good quality cultivars. Such cultivars are also desired to be adapted to wide range of environments. Besides the genotypes, yield and quality traits are also greatly influenced by environmental factors (Liu et al., 2016; Mehraj et al., 2017). The success of plant breeding in the last century has mainly depended on the utilization of natural or mutant modified genetic variation accompanied with efficient selection and suitable methods in target environments. Local cultivars, is a significant natural genetic source, provide a many opportunities to breeders for developing a new varieties with a high yield and quality. Due to the climatic and geographic location, Turkey is the origin of many wild and cultivated plants. So the genetic diversity is very high. There are many different local and wild oat varieties in Turkey. Therefore, Turkey is considered to be one of the important origin centers of the oat (Dumlupinar et al., 2011).

Researches have been conducted to improve the yield and quality traits oat genotypes under different environmental conditions. Genotype $\times$ environment interactions then become significant when the genotypes were grown in several different environments (Kharatukulova et al., 2015). The genotype $\times$ environment interaction (GEI)) has an effect on selection and recommendation of genotypes for the target environments. Therefore, GEI cannot point out all genetic potentials and environmental conditions. That makes difficult the advice of genotypes by the breeder (Gauch and Zobel, 1996).

AMMI (additive main effects and multiplicative interaction) model is widely used to detect stable genotypes and specify the significance of genotype $\times$ environment interaction (Karimizadeh et al., 2016). In addition, principle component analysis (PCA) of biplot may provide visual inspection of genotype $\times$ environment interaction factors (Gauch and Zobel, 1996).
The objectives of this study are: (i) to evaluate the grain yield and some quality traits of local oat genotypes collected from the West and Middle Black Sea Region of Turkey with different environmental conditions; (ii) to assess genotype $\times$ environment interaction and grain yield stability of genotypes.

\section{Materials and Methods}

\subsection{Plant materials}

In this study, 25 oat genotypes (21 local cultivars and 4 registered varieties) were included. Local cultivars were selected from among 261 local oat cultivars collected from the Central and West Black Sea Regions of Turkey in previous years (Table 1).

\subsection{Experimental site}

This study was performed in two successive years (2010-2011 and 2011-2012) at three different locations, namely Amasya-Suluova (E1, E2) (altitude 495 m, latitude $40^{\circ} 50^{\prime} \mathrm{N}$, longitude $35^{\circ} 39^{\prime} \mathrm{E}$ ), Samsun-Bafra (E3, E4) (altitude $20 \mathrm{~m}$, latitude $41^{\circ} 34^{\prime} \mathrm{N}$, longitude $35^{\circ} 55^{\prime}$ E) and Samsun-Kurupelit (E5, E6) (altitude $195 \mathrm{~m}$, latitude $41^{\circ} 21^{\prime} \mathrm{N}$, longitude $36^{\circ} 15^{\prime} \mathrm{E}$ ) (Table 2).

\subsection{Experimental treatments}

Twenty-five different oat genotypes were grown in a randomized complete block design with four replications at each site under rain-fed conditions. Sowing was performed over $7.2 \mathrm{~m}^{2}$ plots with 6 rows in each at $20 \mathrm{~cm}$ row spacing. Sowing rate was 550 seeds $\mathrm{m}^{-2}$. Sowing dates in Amasya-Suluova, Samsun Bafra and Samsun-Kurupelit sites were respectively on October 20, November 4 and November 6 in 2010, and respectively on October 16, November 3 and November 7 
in 2011. Experiments plots were fertilized with 31.3 $\mathrm{kg} \mathrm{N} \mathrm{ha}^{-1}$ and $80.0 \mathrm{~kg} \mathrm{P}_{2} \mathrm{O}_{5} \mathrm{ha}^{-1}$ at planting and 42.0 $\mathrm{kg} \mathrm{N} \mathrm{ha}{ }^{-1}$ at the beginning of stem elongation stage.
Herbicide was used for weed control at all sites. Harvest was performed in all sites in the fourth week of June of both years.

Table 1. Code, origin and mean values for grain yield and grain quality traits of 25 oat genotypes in six environments.

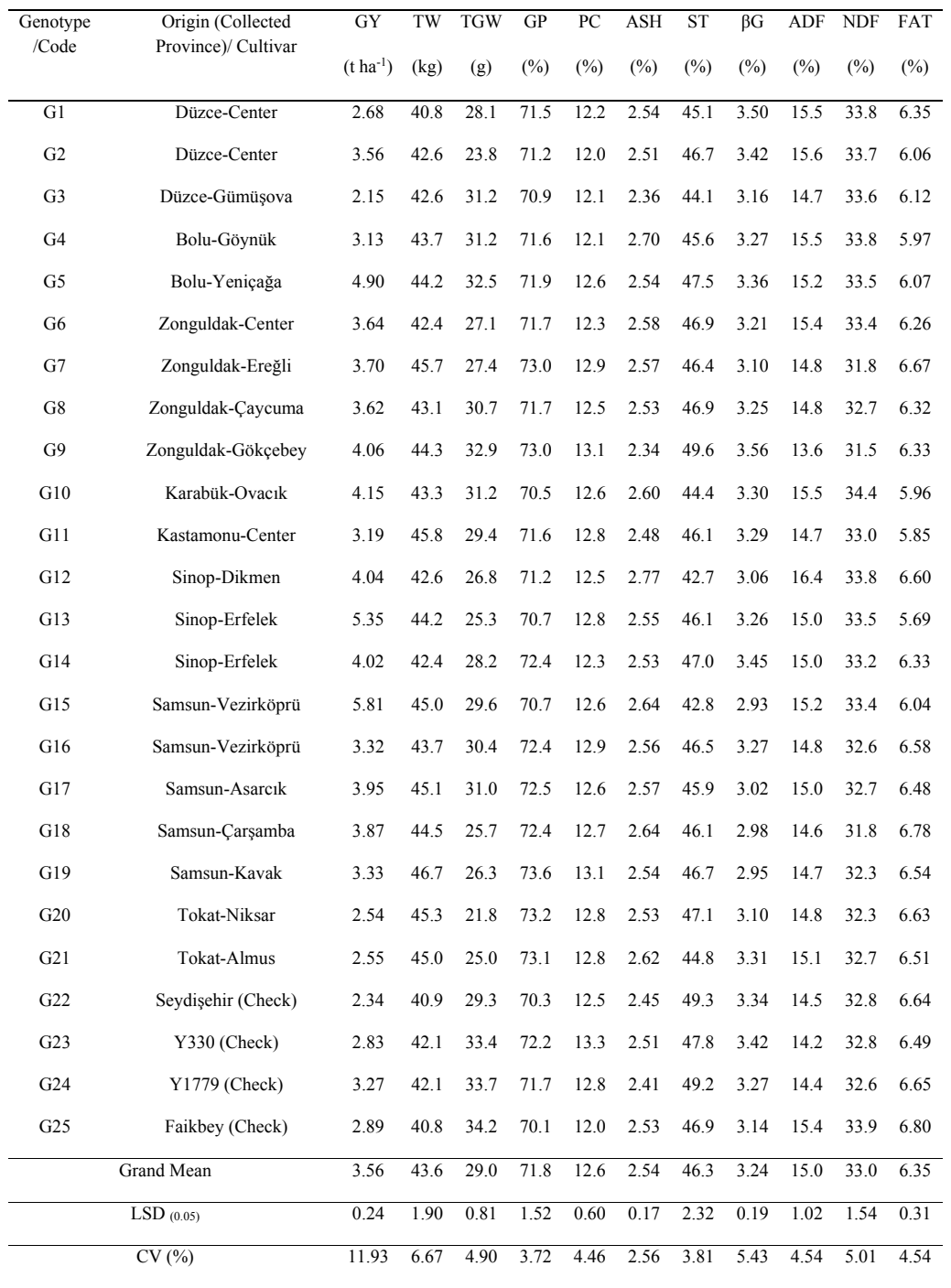

GY; grain yield, TW; test weight, TGW; thousand-grain weight, GP; groat percentage, PC; protein content, ASH; ash content, ST; starch content, $\beta G$; $-\beta$-glucan, ADF; acid detergent fiber, NDF; neutral detergent fiber, FAT;- crude fat. 
Table 2. Agro-climatic characteristics of testing environments

\begin{tabular}{lllcc}
\hline $\begin{array}{l}\text { Growing } \\
\text { Season }\end{array}$ & Environment /Code & Soil Properties & $\begin{array}{c}\text { Altitude } \\
(\mathrm{m})\end{array}$ & $\begin{array}{c}\text { Prediction } \\
(\mathrm{mm})\end{array}$ \\
\hline 2010-2011 & Amasya-Suluova /E1 & $\mathrm{pH}=7.65$ clayey loam & 495 & 634.4 \\
$2011-2012$ & Amasya-Suluova /E2 & $\mathrm{pH}=7.45$ clayey loam & 495 & 415.0 \\
$2010-2011$ & Samsun- Bafra /E3 & $\mathrm{pH}=6.95$ clayey loam & 20 & 854.4 \\
$2011-2012$ & Samsun-Bafra /E4 & $\mathrm{pH}=7.15$ clayey loam & 20 & 945.6 \\
$2010-2011$ & Samsun-Kurupelit /E5 & $\mathrm{pH}=7.10$ clayey & 195 & 788.2 \\
& & & & \\
$2011-2012$ & Samsun-Kurupelit /E6 & $\mathrm{pH}=6.75$ clayey & 195 & 804.2 \\
& & & & \\
\hline
\end{tabular}

\subsection{Grain yield, physical and chemical analyses}

Grain yield (GY) per hectare was calculated from the harvested area of each plot for six environments. Test weight (TW) was measured by using 0.5 liter measuring instrument (AACC, 2000). Thousand-grain weight was obtained by counting and weighing four samples of 100 grains. Groat percentage was evaluated by manually de-hulling $10 \mathrm{~g}$ oat grain sample in two replications, weighing de-hulled groats and calculating proportion of groat. Oat samples for chemical analysis were ground to pass through $1 \mathrm{~mm}$ sieve in a hammer mill and stored for later analyses. Chemical composition (crude protein, fat, ash and starch) of oat grains was determined according to the standard Official Methods of Analysis of the Association of Official Analytical Chemists (AOAC). Protein content was determined by the Kjeldahl methods. Fat was extracted by the Soxhlet method. Acid detergent fiber (ADF) and neutral detergent fiber (NDF) were determined by using an ANKOM 220 Fiber Analyzer. The starch content was determined according to Ewers Polarimetric Method. The $\beta$-glucan was measured with the enzymatic method
(McCleary and Codd, 1991). This method is accepted by the AACC method 32-23 (AACC, 2000).

\subsection{Statistical analysis}

Components of variance were computed by ANOVA analysis considering the genotype as a fixed factor and all environments as random, using a PROC MIXED (SAS, 1998). Means were compared with LSD test $(p<0.05)$. The grain yield data for 25 genotypes in 6 environments were subjected to combine and AMMI analysis of variance using SAS (SAS, 1998).

Genotypic and environmental scores and principal component axes (PCAs) were provided and statistically tested by Gollob's (1968) F test.

The AMMI model is defined in Equation 1 (Gauch and Zobel, 1996):

$$
\mathrm{Y}_{g e r}=\mu+\alpha_{g}+\beta_{e}+\Sigma_{n} \lambda_{n} \gamma_{g n} \delta_{e n}+\rho_{g e}+\varepsilon_{g e r}
$$

Where; $\mathrm{Y}_{\text {ger }}$ is the grain yield of genotype $\mathrm{g}$ in environment e for replicate $r, \mu$ is the grand mean, $\alpha_{\mathrm{g}}$ is the deviation of genotype $g$ from the grand mean, $\beta \mathrm{e}$ is 
the deviation of environment e (additive parameters), $\lambda_{\mathrm{n}}$ is the singular value for interaction principal component axis (IPCA) $n, \gamma_{\mathrm{gn}}$ is the genotype eigenvector for axis $n, \delta_{e n}$ is the environment eigenvector (multiplicative parameters), $\rho_{\mathrm{ge}}$ is residuals of variability not covered by the model, $\varepsilon_{\text {ger }}$ is the experimental error. AMMI stability value (ASV) was also used as an additional parameter of stability according to Purchase (1997) and this parameter was calculated by using Equation 2;

$$
\mathrm{ASV}=\sqrt{\frac{S S_{I P C 1}}{S S_{I P C 2}} *(I P C A 1)^{2}+(I P C A 2)^{2}} \quad \text { Equation } 2
$$

Where; ASV is AMMI stability value, SS is the sum of squares, IPCA1 is the first interaction principal component axis, IPCA2 is the second interaction principal component axis.

\section{Results}

The effects of genotype, environment and their interactions on all traits (grain yield, test weight, thousandgrain weight, groat percentage, protein content, ash, starch content, $\beta$-glucan content, acid detergent fiber $(\mathrm{ADF})$, neutral detergent fiber (NDF) and fat content) were found to be significant $(\mathrm{P}<0.01)$ (Table 3). The ANOVA also showed that out of the total sum of squares, $41.27,32.10$ and $26.63 \%$ for grain yield, $59.80,28.18$ and $12.02 \%$ for test weight, $47.14,29.49$ and $23.37 \%$ for thousand grain weight, $35.31,42.22$ and $22.48 \%$ for groat percent, $38.31,37.49$ and 24.20 $\%$ for protein content, $38.87,38.18$ and $22.95 \%$ for ash, 44.39, 37.91 and $17.70 \%$ for starch content, $36.07,41.01$ and $22.97 \%$ for $\beta$-glucan content, 41.09, 30.88 and $17.98 \%$ for ADF, 39.66, 36.02 and 24.32 $\%$ for NDF, 32.49, 50.91 and $16.59 \%$ for fat content were attributable to environment, genotype and genotype $\times$ environment interaction effects, respectively.

Table 3. Analysis of variance for grain yield and some quality traits of 25 oat genotypes in different environments

\begin{tabular}{|c|c|c|c|c|c|}
\hline Source of variation & Environment (E) & Rep/environment & Genotype (G) & EX G & Errol \\
\hline $\mathrm{df}$ & 5 & 18 & 24 & 120 & 432 \\
\hline GY & $44.6^{* *}$ & 0.43 & $9.3 * *$ & $1.3^{* *}$ & 0.08 \\
\hline TW & $1018^{* *}$ & 6.57 & $124.2 * *$ & $10.2^{* *}$ & 2.1 \\
\hline TGW & $1366.9^{* *}$ & 3.33 & $228.7 * *$ & $27.59 * *$ & 1.03 \\
\hline GP & $1085.6^{* *}$ & 6.31 & $332.2 * *$ & $29.06^{* *}$ & 2.16 \\
\hline $\mathrm{PC}$ & $141.73^{* *}$ & 2.33 & $36.06 * *$ & $3.62 * *$ & 0.13 \\
\hline $\mathrm{ASH}$ & $28.25 * *$ & 0.06 & $7.21^{* *}$ & $0.72 * *$ & 0.07 \\
\hline ST & $2720.9 * *$ & 8.88 & $596.9 * *$ & $49.28 * *$ & 6.67 \\
\hline$\beta G$ & $19.8^{* *}$ & 0.24 & $5.8^{* *}$ & $0.55 * *$ & 0.06 \\
\hline $\mathrm{ADF}$ & $301.1 * *$ & 2.32 & $59.01 * *$ & $5.72 * *$ & 0.78 \\
\hline NDF & $344.3 * *$ & 5.47 & $82.52 * *$ & $9.55 * *$ & 1.34 \\
\hline FAT & $11.0 * *$ & 0.31 & $4.3 * *$ & $0.25 * *$ & 0.03 \\
\hline
\end{tabular}

**; Significant at $\mathrm{P}=0.01$ 
Significant $\mathrm{G} \times \mathrm{E}$ interaction demonstrated that yield responses of the genotypes were altered by the environments. The means for grain yield ranged from 2.48 $\mathrm{t} \mathrm{ha}^{-1}$ in environment $\mathrm{E} 1$ to $4.19 \mathrm{t} \mathrm{ha}^{-1}$ in environment E4 (Table 4). Grain yield of the genotypes averaged over all environments ranged from $2.15 \mathrm{t} \mathrm{ha}^{-1}$ for genotype G3 to $5.81 \mathrm{t} \mathrm{ha}^{-1}$ for genotype G15; the overall mean was $3.56 \mathrm{t} \mathrm{ha}^{-1}$ (Table 1).

Test weights (TW) of the environments varied between $38.9 \mathrm{~kg}$ in environment $\mathrm{E} 4$ and $45.7 \mathrm{~kg}$ in environments E1 and E5. Test weight and thousand-grain weights of the genotypes respectively varied between 40.8 and $46.7 \mathrm{~kg}$ and between 21.8 and $34.2 \mathrm{~g}$. The greatest test weights were obtained from the genotypes G19, G11, G7, G20, G17, G15, G21 and G18, and the lowest values were obtained from the genotypes G1, G22 and G25 (Table 1).

The greatest thousand-grain weight was obtained from the environment E2 $(35.0 \mathrm{~g})$ and lowest from the environment E4 (25.4 g). According to the average of the tested environments, the greatest thousand-grain weights were achieved from genotypes G25, G24, G23 and G9, and the lowest thousand grain weights were obtained from the genotypes G20, G2, G21 and G13 (Table 1).

The highest groat percentage was obtained from the environment E6 (76.8\%) and the lowest from the Environment E3 (67.4\%). According to the average of the tested environments, the groat percentages varied between 70.1 and $73.6 \%$, and the greatest values were obtained from the genotypes G19, G20, G21, G7 and G9 (Table 1).

Protein contents of the environments varied between 10.9 (environment E4) and 14.1\% (environment E2); ash contents between 1.99 (environment E5) and 3.53 \% (environment E4); starch contents between 36.1 (environment E4) and 51.8\% (E5); $\beta$-glucan contents between 2.79 (environment E1) and 4.13\% (environment E6); ADF contents between 12.1 (environment E5) and $17.3 \%$ (environment E3); NDF contents between 30.0 (environment E5) and 35.5\% (environment E3) and finally fat contents varied between 5.74 (environment E2) and 6.72\% (environment E1) (Table 4).

Table 4. Mean values for grain yield and some quality traits in six environments recorded for 25 oat genotypes.

\begin{tabular}{|c|c|c|c|c|c|c|c|c|c|c|c|c|}
\hline Environment & Env. & GY & TW & TGW & GP & PC & $\mathrm{ASH}$ & ST & $\beta G$ & ADF & NDF & FAT \\
\hline (location and year) & Code & & & & & & & & & & & \\
\hline Amasya-Suluova (2010-11) & E1 & 3.27 & 45.7 & 29.8 & 74.6 & 13.1 & 2.49 & 50.1 & 2.79 & 14.2 & 31.6 & 6.72 \\
\hline Amasya- Suluova (2011-12) & E2 & 2.48 & 45.6 & 35.0 & 73.1 & 14.1 & 2.35 & 49.7 & 3.20 & 14.1 & 33.1 & 5.74 \\
\hline Samsun-Bafra 1 (2010-2011) & E3 & 3.91 & 39.8 & 26.0 & 67.4 & 11.7 & 2.85 & 45.0 & 2.86 & 17.3 & 35.5 & 6.54 \\
\hline Samsun-Bafra (2010-2011) & E4 & 4.19 & 38.9 & 25.4 & 68.7 & 10.9 & 3.53 & 36.1 & 2.94 & 16.4 & 34.7 & 6.45 \\
\hline Samsun-Kurupelit (2010-2011) & E5 & 3.82 & 45.7 & 30.7 & 70.3 & 14.0 & 1.99 & 51.8 & 3.50 & 12.1 & 30.0 & 6.33 \\
\hline Samsun-Kurupelit (2011-2012) & E6 & 3.64 & 45.5 & 27.4 & 76.8 & 11.8 & 2.05 & 45.3 & 4.13 & 15.7 & 33.3 & 6.31 \\
\hline $\operatorname{LSD}_{(0.05)}$ & & 0.12 & 0.93 & 0.40 & 0.74 & 0.30 & 0.08 & 1.14 & 0.09 & 0.50 & 0.75 & 0.15 \\
\hline
\end{tabular}


Protein is the basic parameter designating the quality of oat grains. The highest grain protein contents were obtained from the genotypes G23 (13.3\%), G19 (13.1\%), G9 (13.1), G7 (12.9\%) and G16 (12.9\%), and the lowest values were obtained from the genotypes G25 (12.0\%), G2 (12.0\%), G5 (12.1\%), G4 $(12.1 \%)$ and G1 (12.2\%) (Table 1).

While the genotypes G9, G3, G24, G22 and G11 had the lowest ash content, the genotypes G12, G4, G18, G15 and G21 had the highest ash content. In this study, the highest starch contents were obtained from the genotypes G9 (49.6\%), G22 (49.3\%), G24 (49.2\%), G23 (47.8\%) and G3 (47.5\%), and the lowest starch contents were obtained from the genotypes G12 (42.7\%), G15 (42.8\%), G5 (44.1\%), G10 (44.4\%) and G21 (44.8\%) (Table 1).

The $\beta$-glucan contents of six environments varied between 2.93 to $3.56 \%$. The greatest $\beta$-glucan contents were obtained from the genotypes G9 (3.56\%), G14 (3.45\%), G23 (3.42\%), G2 (3.42\%) and G3 (3.36\%), respectively (Table 1).

According to the average of the environments, the means for ADF and NDF ranged from 13.6 to $16.4 \%$ and 31.5 to $34.4 \%$, respectively. The lowest ADF and NDF values were obtained from the genotypes G9, G18, G7, G19, G20, G24 and G16 (Table 1).

Owing to the valuable fatty acid composition of oat grain fat, the oat has a high nutritional potential. Oat genotypes usually include more fat than the other small cereal grains. In this study, fat concentration of oat genotypes varied between 5.69 and $6.80 \%$. The highest fat concentrations were obtained from the genotypes G25 (6.80\%), G18 (6.78\%), G7 (6.6.7\%),
G24 (6.65\%) and G22 (6.64\%), and the lowest fat concentrations were obtained from the genotypes G13 (5.69\%), G11 (5.85\%), G10 (5.96\%), G4 (5.97\%), and G15 (6.04) (Table 1).

The AMMI analysis of variance for grain yield of twenty-five oat genotypes grown in six environments showed that $41.27 \%$ of the total sum of squares was assignable to environmental effects, $32.10 \%$ to genotypic effects, and $26.63 \%$ to genotype $\mathrm{x}$ environment interaction as presented in Table 5. AMMI analysis revealed the significance of four interaction principal component axes (IPCA) for grain yield. The data obtained from the AMMI analysis also indicated that the first two IPCAs of the interaction were able to explain 46.44 and $27.80 \%$ of total variation, respectively. The mean squares for the IPCA 1 and IPCA 2 were significant and cumulatively subscribed to $74.24 \%$ of the total GEI (Table 5). To represent the effect of each genotype and environment, Figure 1 and Figure 2 were presented. According to Figure 1, environments showed high variation both in main effects and interactions. While the environment E6 had low interaction; E3, E4 and E1 were highly interactive. E4 and E3 were the most favorable environments and E1 and E2 were the least favorable environments, while E5 was the average environment. As seen in Figure 1, genotype G7 was the most stable genotype, followed by the genotypes G17, G12, G15, G8, and G5. On the other hand, the genotypes G2, G6, G9, G10, G13, and G14 had moderately large IPCA1 scores and grain yields greater than the grand mean. Therefore, these genotypes were assessed as less stable. 
Table 5. AMMI analysis for grain yield $\left(\mathrm{t} \mathrm{ha}^{-1}\right)$ of 25 genotypes evaluated in 6 environments

\begin{tabular}{cccccc}
\hline Source & DF & Sum of square & $\begin{array}{c}\text { Mean of } \\
\text { squares }\end{array}$ & F Ratio & Explained (\%) \\
\hline Model & 152 & 602.19 & 3.96 & 49.52 & \\
Environment & 5 & 223.02 & 44.60 & $557.5^{* *}$ & 41.27 \\
Genotype & 24 & 223.24 & 9.30 & $116.25^{* *}$ & 32.10 \\
G × E & 120 & 155.92 & 1.30 & $16.25^{* *}$ & 26.63 \\
Interaction PCA 1 & 28 & 72.40 & 2.59 & $32.38^{* *}$ & 46.44 \\
Interaction PCA 2 & 26 & 43.34 & 1.67 & $20.88^{* *}$ & 27.80 \\
Interaction PCA 3 & 24 & 27.18 & 1.13 & $14.12^{* *}$ & 17.43 \\
Interaction PCA 4 & 22 & 7.80 & 0.35 & $4.38^{* *}$ & 4.99 \\
Interaction PCA 5 & 20 & 5.20 & 0.26 & 3.25 & 3.34 \\
Interaction PCA 6 & 18 & 0.00 & 0.00 & 0.00 & 0.00 \\
Pooled Error & 447 & 35.79 & 0.08 & & \\
C. Total & 599 & 637.98 & & & \\
\hline \multicolumn{7}{c}{$\mathrm{CV}(\%), 11.93$} & $\mathrm{R}^{2}, 92.3$ & \\
\hline
\end{tabular}

$* * \mathrm{P}<0.01, \mathrm{DF}=$ degree of freedom; tabulated frequency, $\mathrm{CV}$, Coefficient of variation, $\mathrm{R} 2$, correlation coefficient of multiple determination.

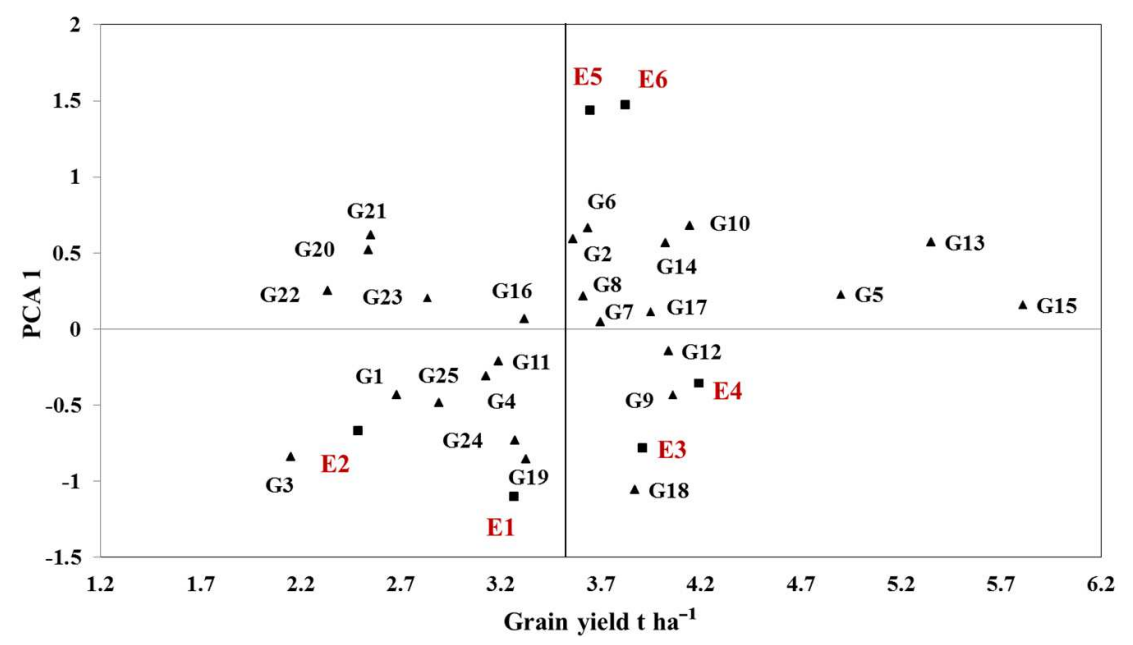

Figure 1. Biplot analysis of GEI based on AMMI 1 model for the PCA1 scores and grain yield 


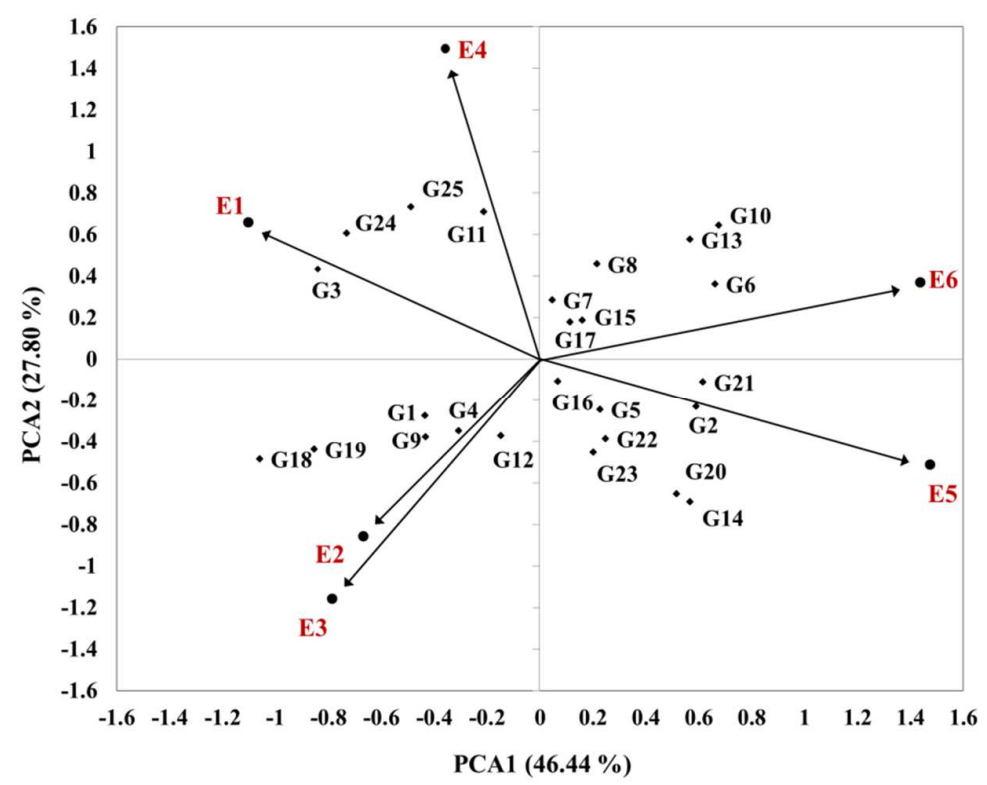

Figure 2. Biplot analysis of GEI based on AMMI 2 model for the first two interactions principal component scores

The IPCA1 and IPCA2 scores of genotypes and environments were arranged for AMMI2 biplot analysis to show the relative magnitude of the $\mathrm{G} \times \mathrm{E}$ interaction (Figure 2). The environments E1, E3, E4, E5 and E6 largely contributed to the $\mathrm{G} \times \mathrm{E}$ interaction, because they were positioned far from the origin in the AMMI2 biplot. The genotypes G5, G7, G12, G15, G16 and G17 were the most stable ones. Then, these genotypes were localized near the origin of the biplot. However, G16 had grain yield lower than the grand mean. The genotypes G6, G10 and G13 had a specific adaptation to environment E4, while the genotypes G3 and G24 adapted to environment E1 and G18 and G19 to environment E2 (Figure 2).
The ASV as defined by Purchase (1997) was calculated for each genotype (Table 6). Genotypes with lower ASV values are considered more stable than the genotypes with higher ASV. Based on AMMI stability value (ASV), the genotypes G16, G17, G15, G7, G5 and G12 had the lowest values, respectively. Hence, these genotypes were identified as the most stable genotypes. From these genotypes, G15 and G5 genotypes were the first and third highest yielder based on the average yield value. On the other hand, according to ASV, the genotypes G14, G10, G18, G19, G3 and G24 were identified as unstable genotypes in tested environments (Table 6). 
Table 6. Mean yield and ASV values of 25 oat genotypes.

\begin{tabular}{rcccccccccc}
\hline $\begin{array}{r}\text { Genotype } \\
\text { code }\end{array}$ & $\begin{array}{c}\text { GY } \\
\left.(\mathrm{t} \mathrm{ha})^{-1}\right)\end{array}$ & Rank & ASV & Rank & $\begin{array}{c}\text { Genotype } \\
\text { code }\end{array}$ & $\begin{array}{c}\text { GY } \\
\left.(\mathrm{t} \mathrm{ha})^{-1}\right)\end{array}$ & Rank & ASV & Rank \\
\hline G1 & 2.68 & 21 & 0.6231 & 11 & G14 & 4.02 & 7 & 1.0092 & 20 \\
G2 & 3.56 & 13 & 0.7977 & 14 & G15 & 5.81 & 1 & 0.2802 & 3 \\
G3 & 2.15 & 25 & 1.1685 & 23 & G16 & 3.32 & 15 & 0.1382 & 1 \\
G4 & 3.13 & 18 & 0.5292 & 9 & G17 & 3.95 & 8 & 0.2332 & 2 \\
G5 & 4.90 & 3 & 0.3834 & 5 & G18 & 3.87 & 9 & 1.4503 & 25 \\
G6 & 3.64 & 11 & 0.9309 & 16 & G19 & 3.33 & 14 & 1.1863 & 24 \\
G7 & 3.70 & 10 & 0.2925 & 4 & G20 & 2.54 & 23 & 0.9338 & 17 \\
G8 & 3.62 & 12 & 0.5369 & 10 & G21 & 2.55 & 22 & 0.8054 & 15 \\
G9 & 4.06 & 5 & 0.6741 & 12 & G22 & 2.34 & 24 & 0.5034 & 7 \\
G10 & 4.15 & 4 & 1.0881 & 21 & G23 & 2.83 & 20 & 0.5243 & 8 \\
G11 & 3.19 & 17 & 0.7609 & 13 & G24 & 3.27 & 16 & 1.1201 & 22 \\
G12 & 4.04 & 6 & 0.4181 & 6 & G25 & 2.89 & 19 & 0.9646 & 19 \\
G13 & 5.35 & 2 & 0.9343 & 18 & Mean & 3.56 & & & \\
\hline
\end{tabular}

\section{Discussion}

The environmental variance components were much larger than the genotypic variance components for GY, TW, TGW, PC, ASH, STRACH, ADF and NDF in this study. Doehlert et al. (2001) stated that the effects of environment on grain yield, starch and ash contents were higher than the genotype, while the genotype and environment showed equal effects on hectoliter weight, hull content, groat weight, protein content and $\beta$-glucan concentration. Authors also reported the effect of the genotype on groat fat content was stronger as compared to the environment. Furthermore, it was indicated that the variability of chemical quality properties in oat compared to other grains was more affected by the environment factors (Yan et al., 2016). That is why, it is very important to determine the yield, quality traits and the relationships between yield and quality traits of oat genotypes cultivated in various environments. This may help breeders to develop high-yield and high-quality varieties suitable for the region.

The significant $G \times E$ interaction demonstrated that yield responses of genotypes were altered by the environments. Variation between environments in terms of grain yield may be due to precipitation sum, precipitation distribution and temperature of the environment (Table 2). Factors designating the yield and quality of field crops can be categorized into several groups: genotype efficiency, soil fertility, agricultural practices and meteorological conditions (Abunyewa et al., 2017). The genotype and climate conditions are significant parameters with great influences on yield and quality of oat (Burstmayer et al., 2007). Hellewell et al. (1996) reported that yield and quality of oat were significantly affected by photosynthetically active radiation, heat and soil moisture in certain phases of plant development. The change in yield of genotypes may be related to genetic structures and adaptability of these genotypes to different environments. Burstmayer et al. (2007) and Yan et al. (2016) indicated significant impacts of genotype and environment on grain yields.

Test weight, thousand-grain weight and groat percentage are important yield components for oats. Oat cultivars with higher values of these parameters are generally considered to be of higher quality than those with low values. Based on the average test weights (TW) 
for six environments, thirteen of the twenty five genotypes had higher value than the average found in the trials. Załuski et al. (2016) reported that the main reason for the popularity of test weight was its simplicity. Therefore, it is effectively used in estimating the hull content and milling yield. It is also used in detecting grains damaged by unfavorable environmental conditions, diseases or inadequate cultural practices. Some researchers (Buerstmayr et al., 2007; Załuski et al., 2016) emphasized that thousand-grain weight was a genotype-specific trait, with notably higher variations being realized among genotypes than among the treatments or environments. Low hull content is particularly important to achieve high milling yield, which is an important criteria for hulled food oat (Cowan and Valentine, 2004). Tamm (2003) stated that grain yield and physical grain quality were largely influenced by climate and genetic conditions.

Protein content is the primary quality indicator for oat grains. Protein contents can change by as much as 3-4 $\%$ within the same cultivar when it was cultivated in different geographical regions. Peterson et al. (2005) reported that the grain protein content changed from 10.0 to $18.0 \%$ in hulled oat genotypes and protein content of oat grain changed significantly in connection with the genotypes.

Environment was the dominant factor contributing to the total variation of starch content (Rhymer et al., 2005). Givens et al. (2004) reported that starch contents ranged from 40.0 to $42.9 \%$ in two cultivars of the UK. Moreover, Doehlert et al. (2013) stated that starch contents varied between 51.1 and 59.2\% in different oat genotypes. Rhymer et al. (2005) indicated that starch content differences were influenced by genotype in five Canadian oat genotypes.

Demirbaş, (2005) carried out a study with cereal grains and reported that oat groats had the highest $\beta$-glucan contents and. The $\beta$-glucan content of oat genotypes varied between 1.33 and $2.58 \%$ in present study. It was reported in a previous study that reference $\beta$-glucan contents ranged from 0.77 to $8.37 \%$ in hulled and hulless oat genotypes (Givens et al., 2000). $\beta$-glucan aids in decreasing blood glucose and cholesterol levels (Demirbaş, 2005).

Biel et al. (2014) indicated that ADF and NDF values of hulled oat grains were higher than the values of the other cereal grains. Researchers also reported that average ADF and NDF values for hulled oats were 16.4 and $38.1 \%$, respectively, which were higher than the values found in present study.

Owing to the valuable fatty acid composition, oats have quite high nutritional potential. Oat genotypes usually include higher fat ratios than the other small cereal grains. In this study, fat concentration of oat genotypes varied between 5.69 and 6.80\%. Mut et al. (2016) reported fat concentrations of twenty-five oat genotypes as between 5.86 and $8.47 \%$. In another study, fat contents of more than 4000 oat genotypes were reported as between 3.1 and $11.6 \%$.

AMMI analysis revealed the significance of four interaction principal component axes (IPCA) for grain yield. The mean squares for the IPCA 1 and IPCA 2 were significant and cumulatively subscribed to $74.24 \%$ of the total GEI and, hence, the best-fit model for AMMI can be noticed by using the first two PCs to explain interpretable patterns of the interactions (Gauch and Zobel, 1996). Similar conclusions about the participation of principal components in sum of square of interaction were also drawn by Yan and Kang (2003). The IPCA values of genotypes in AMMI analysis are the signs of stability and adaptability over environments and association between genotypes and environments (Gauch and Zobel 1996; Purchase, 1997). According to AMMI model, the genotypes with higher means than the grand mean value and the IPCA 1 nearly zero are considered as stable. But, the genotypes with high IPCA scores are thought to having specific adaptation for certain environments. Genotypes 
with lower ASV values are considered more stable than genotypes with higher ASV (Karimizadeh et al., 2016).

\section{Conclusions}

It was concluded based on present findings that the genotypes, the environment and their interaction had highly significant effects on grain yield and quality traits of oat genotypes cultivated in six different environments. The genotypes G5, G7, G12, G15 and G17 were found to be the most stable cultivars for grain yield. Also, these genotypes had higher grain yields than the standard cultivars for tested environments. In addition, these genotypes had high values for the desired quality traits of oat grains. Therefore, these genotypes can be recommended for tested environments and similar environments. The primary goal of plant breeders is to identify high-yield and quality genotypes not only to provide quality raw material for end users, but also to provide parents for the future breeding programs. Present findings revealed that quality traits were more promising as selection criteria and local cultivars had promising outcomes for gain yield.

\section{References}

AACC. 2000. Approved Methods of American Association of Cereal Chemists. $10^{\text {th }} \mathrm{Ed}$. American Association of Cereal Chemists, Minnesota, USA.

Abunyewa, A.A., Ferguson, R.B., Wortmann, C.S., Mason, S.C. 2017. Grain sorghum nitrogen use as affected by planting practice and nitrogen rate. Journal of Soil Science and Plant Nutrition. 17, 155-166.

Biel, W., Jacyno, E., Kawecka, M. 2014. Chemical composition of hulled, dehulled and naked oat grains. South African Journal of Animal Science. 44, 189-197.
Buerstmayr, H., Krenn, N., Stephan, U., Grausgruber, H., Zechner, E. 2007. Agronomic performance and quality of oat (Avena sativa L.) genotypes of worldwide origin produced under central European growing conditions. Field Crops Research. 101, 343-351.

Cowan, S., Valentine, J. 2004. New directions in breeding for high quality oats. In, Proceedings of 7th International Oat Conference, Agrifood Research Reports 51, MTT Agrifood Research Peltonen-Sainio, P.M., Topi-Hulmi, editors, Jokioinen, Finland, pp: 45-50.

Demirbaş, A. 2005. ß-Glucan and mineral nutrient contents of cereals grown in Turkey. Food Chemistry. 90, 773-777.

Doehlert, D.C., McMullen, M.S., Hammond, J.J. 2001. Genotypic and environmental effects on grain yield and quality of oat grown in North Dakota. Crop Sci. 41, 1066-1072.

Doehlert, D.C., Simsek, S., Thavarajah, D., Thavarajah, P., Ohm, J. 2013. Detailed composition analyses of diverse oat genotype kernels grown in different environments in North Dakota. Cereal Chemistry. 90, 572-578.

Dumlupınar, Z., Meral, H., Kara, R., Dokuyucu, T., Akkaya, A. 2011. Evaluation of Turkish oat landraces based on grain yield, yield components and some quality traits, Turkish Journal of Field Crops. 16, 190-196.

Gauch, H.G., Zobel, R.W. 1996. AMMI analysis of yield trials. In genotype-by-environment Interaction, Kang, M.S. and H.G. Gauch, editors, CRC Press, Boca Raton, FL, pp: 85- 122.

Givens, D.I., Davies, T.W., Laverick, R.M. 2000. Dietary fibre fractions in hulled and naked winter oat grain, Effects of cultivar and various agronomic factors. Journal of the Science of Food and Agriculture. 80, 491-496. 
Givens, D.I., Davies, T.W., Laverick, R.M. 2004. Effect of variety, nitrogen fertilizer and various agronomic factors on the nutritive value of husked and naked oats grain. Anim. Feed Sci. Technol. 113, 169-181.

Gollob, H.F.A. 1968. Statistical model which combines features of factor analytic and analysis of variance techniques. Psychometrika. 33, 73-115.

Hellewell, K., Stuthman, D., Merkhart, F., Erwin, J. 1996. Day and night temperature effects during grain-filling in oat. Crop Science. 36, 624-628.

Karimizadeh, R., Asghari, A., Chinipardaz, R., Sofalian, O., Ghaffari, A. 2016. Determining yield stability and model selection by AMMI method in rain-fed durum wheat genotypes. Turk. J. Field Crops, 21, 174-183.

Kharatukulova, S., Sharma, R.C., Amanov, A. Ziyadullaev, Z., Amanov, O., Alikulov, S., Ziyaev, Z., Muzararova, D. 2015. Genotype $\times$ environment interaction and stability of grain yield andselected quality traits in winter wheat in Central Asia. Turk J. Agric. For. 39, 920-929.

Liu, H., Gan, W., Rengel, Z., Zhao, P. 2016. Effects of zinc fertilizer rate and application method on photosynthetic characteristics and grain yield of summer maize. Journal of Soil Science and Plant Nutrition, 16, 550-562.

McCleary, B.V., Codd, R. 1991. Measurement of $(1 \rightarrow 3),(1 \rightarrow 4)-\beta$-Dglucan in barley and oats, A streamlined enzymic procedure. Journal Science Food Agricultural. 55, 303-312.

Mehraj, U., Abidi, I., Ahmad, M., Gul-Zaffar, Z.A., Dar, Rather, M.A., Lone, A.A., 2017. Stability analysis for physiological traits, grain yield and its attributing parameters in oats (Avena sativa L.) in the Kashmir Valley. Electronic Journal of Plant Breed. 8, 59-62.
Mut, Z., Erbas Kose, O.D., Akay, H. 2016. Grain yield and some quality trait of naked oat cultivars. Anadolu Journal of Agricultural Sciences. 31, 96-104.

Peterson, D.M., Wesenberg, D.M., Burrup, D.E., Erickson, C.A. 2005. Relationships among agronomic traits and grain composition in oat genotypes grown in different environments. Crop. Sci. $45,1249-1255$.

Purchase, R.L. 1997. Parametric analysis to describe genotype by environment interaction and yield stability in winter wheat. Ph.D. Thesis, Department of Agronomy, Faculty of Agriculture of the University of the Free State, Bloemfontein, South Africa.

Rhymer, C., Ames, N., Malcomson, L., Brown, D., Duguid, S., 2005. Effects of genotype and environment on the starch properties and end-product quality of oats. Cereal. Chem. 82, 197-203.

SAS Institute. 1998. SAS proprietary software. Release 8.2. SAS Inst., Cary, NC.

Tamm, I. 2003. Genetic and environmental variation of grain yield of oat varietes. Agronomy Research. 1, 93-97.

Yan, W., Kang, M.S. 2003. GGE Biplot analysis, a graphical tool for breeders, geneticists, and agronomists. CRC Press, Boca Raton, Florida.

Yan, W., Frégeau-Reid, J., Pageau, D., Martin, R. 2016. Genotype-by-environment interaction and trait associations in two genetic populations of oat. Crop Sci. 56, 1136-1145.

Załuski, D., Dubis, B. Budzyński, W., Jankowski, K. 2016. Applicability of the 35-2 Fractional Factorial Design in Determining the Effects of Cultivation Factors on Hulless Oat. Agron. J. 108, 205-218. 